\title{
The Characterization and Cloning of a Gluconate (gnt) Operon of Bacillus subtilis
}

\author{
By YASUTARO FUJITA, ${ }^{*}$ JUN-ICHI NIHASHI† AND TAMIE FUJITA \\ Department of Biochemistry, Hamamatsu University School of Medicine, 3600 Hando-cho, \\ Hamamatsu 431-31, Japan
}

(Received 17 June 1985; revised 12 August 1985)

\begin{abstract}
The enzymes involved in gluconate utilization in Bacillus subtilis seemed to be gluconate permease and gluconate kinase. Several mutants unable to grow on gluconate were isolated. The mutations they harboured (gnt) were clustered between iol-6 and $f d p-74$ on the $B$. subtilis chromosome (a tentative map order of $g n t-10$, gnt -4, gnt-26, gnt-23 and gnt-9 was obtained). The gnt-10 mutation seemed to be located within the structural gene of the kinase, and the gnt-23 and gnt-26 mutations seemed to be within that of the permease. An EcoRI fragment (4.5 MDal) containing an intact gluconate ( $g n t)$ operon consisting of these two structural genes was cloned in phage $\phi 105$ by prophage transformation and was mapped physically. The physical location of the mutations coincided with their order on the genetic map. The HindIII-A fragment (2.4 MDal), which corrects all the gnt mutations, was subcloned in plasmid pC194. The fragment contained the structural genes for the gluconate permease and kinase, but not the regulatory region of the gluconate operon.
\end{abstract}

\section{INTRODUCTION}

After entering the Bacillus subtilis cell, gluconate is phosphorylated to gluconate 6-phosphate, which, because $B$. subtilis lacks the Entner-Doudoroff pathway, can only be metabolized through the pentose cycle. Therefore, only two enzymes may be needed for the utilization of gluconate as a carbon source; one is gluconate permease, which transports gluconate into the cell, and the other is gluconate kinase, which phosphorylates gluconate. Both enzymes are induced in response to gluconate and their induction is repressed in the presence of rapidly metabolizable carbohydrates such as glucose (Dowds et al., 1978; Nihashi \& Fujita, 1984). We have tentatively reported the cloning of the genes for gluconate utilization in a temperate phage, oll (Fujita et al., 1983). In this paper, we communicate the genetic mapping and characterization of several gnt mutations that render the cell unable to grow on gluconate and we also report the recloning of an EcoRI fragment cloned in $\rho 11$ in another temperate phage, $\phi 105$. This fragment encodes an intact gluconate operon. To our knowledge, this work is the first example of the use of a $B$. subtilis host -vector system to clone an intact catabolic operon of this species.

\section{METHODS}

Bacteria, phage and plasmids. Strain 60015 (trpC2 metC7) is our standard strain. Among $\mathrm{Gnt}^{-}$mutants, the isolation of strain 61656 ( $\wedge$ igf hisAl leuA8 metB5 trpC2), YF127 (gnt-4 trpC2 metC7) and YF029 (gnt-9 purAl6 leuA8 metB5 hisA3) has already been reported (Fujita \& Freese, 1981; Fujita \& Fujita, 1983). Strain YF158 (gnt-4 recE4 trpC2) was constructed from $\mathrm{YF} 127$ by congression using the DNA of strain 1 A423 (leuA8thr-5 $\arg A 15 \mathrm{rec} E 4 \mathrm{r}^{-} \mathrm{m}^{-}$), which was obtained from the Bacillus Genetic Stock Center, Ohio State University, Columbus, USA. Strain YF160 ( $g n t-10 \operatorname{trp} C 2$ metC7) was isolated from strain 60015 that had been treated with

\footnotetext{
$\dagger$ Present address: Department of Pharmacy, Hospital of Hamamatsu University School of Medicine, 3600 Handa-cho, Hamamatsu 431-31, Japan.
} 
ethylmethane sulphonate, according to the method previously described (Fujita \& Fujita, 1983). Strains YF161 $(\mathrm{gml}-23 \mathrm{trpC} 2 \mathrm{met} \mathrm{C} 7)$ and YFl62 (gnt-26 irpC2 metC7) were isolated as follows. After strain 60015 had been treated with ethylmethane sulphonate, cells were grown in a liquid minimal medium (S6) (Fujita \& Fujita, 1983) containing glucose as sole carbon source and were plated on a solid minimal medium (N) (Fujita \& Fujita, 1983) containing gluconate $(0.1 \%)$ and glucose $(0.01 \%)$ as carbon sources. Among approximately 20000 colonies screened, 1500 tiny colonies were picked and tested for growth on glucose and gluconate. Only two colonies, YF161 and YF162, showed a $\mathrm{Gnt}^{-}$phenotype. The temperate phage, $\phi 105$, was provided by F. Kawamura (Institute of Applied Microbiology, Tokyo University, Japan). Plasmids pUB1 10 and pC194 were obtained from Y. Sadaie (National Institute of Genetics, Mishima, Japan) and the Bacillus Genetic Stock Center, respectively.

Enzyme assays. Gluconate kinase (EC 2.7.1.12) was assayed as described previously (Nihashi \& Fujita, 1984). The enzyme was induced by exposure of cells to $10 \mathrm{~mm}$-gluconate for $2 \mathrm{~h}$.

Gluconate permease was assayed essentially by the method described by Dowds et al. (1978). When cells had grown at $37^{\circ} \mathrm{C}$ to an $\mathrm{OD}_{600}$ of $1.0 \mathrm{in} \mathrm{S} 6$ medium containing $0.5 \%$ Casamino acids (Difco), $3 \mathrm{ml}$ of the culture were harvested and washed in S6 medium plus chloramphenicol $\left(100 \mu \mathrm{g} \mathrm{ml}^{-1}\right)$. Washed cells were suspended in $2 \mathrm{ml}$ of the same medium plus chloramphenicol $\left(100 \mu \mathrm{g} \mathrm{ml}^{-1}\right)$ and used for the permease assay as an uninduced sample. In order to induce the permease, the above culture was diluted four times with the same growth medium and the cells allowed to grow to an $\mathrm{OD}_{\mathrm{tor}}$ of 1.0 for approximately $2 \mathrm{~h}$ in the presence of $10 \mathrm{~mm}$-gluconate. Samples $(3 \mathrm{ml})$ of the culture were harvested, washed and resuspended as described above. The suspension ( $2 \mathrm{ml})$ was used as an induced sample. The assay tube held, at $37^{\circ} \mathrm{C}, 0.7 \mathrm{ml} \mathrm{S} 6$ medium plus chloramphenicol $\left(100 \mu \mathrm{g} \mathrm{ml}^{-1}\right)$ containing D-[U-1 ${ }^{4}$ C]gluconate $\left(0.05 \mu \mathrm{Ci}, 1.9 \mathrm{kBq} ; 5.6 \mathrm{mCi} \mathrm{mol}^{-1}, 210 \mathrm{MBq} \mu \mathrm{mol}^{-1}\right)$ (Amersham) and $93 \mu \mathrm{M}$-gluconate. Incorporation was initiated by the addition of $0.6 \mathrm{ml}$ of the cell suspension to the assay tube. After incubation at $37 \mathrm{C}$ for $30 \mathrm{~s}$, the suspension wals filtered on a premoistened membrane $(25 \mathrm{~mm}$ diameter, $0.45 \mu \mathrm{m}$ pore size) (Toyo Roshi (o.). The filter pad was immediately washed three times with $5 \mathrm{ml} \mathrm{S6}$ medium plus chloramphenicol $\left(100 \mu \mathrm{g} \mathrm{ml}^{-1}\right.$ ). The pad was dried and counted in $10 \mathrm{ml}$ scintillant (ACSII; Amersham)

Transduction and transformation. PBSI-mediated transduction and DNA-mediated transformation were done as described by lijima et al. (1977) and Shibata \& Saito (1973), respectively. Specialized transduction by phages derived from $\phi \mathrm{l} 05$ was done as described by lijima et al. (1980). For selection of $\mathrm{Gnt}^{+}$recombinants, $\mathrm{N}$ medium containing $25 \mathrm{~mm}$-gluconate and enriched with $0.002 \%$ yeast extract (Difco) was used.

Transformation of $\mathrm{Gnt}^{-}$strains by restriction enzyme fragments was done as follows. The gnt ${ }^{+}$fragment $(1 \mu \mathrm{g})$ was digested with $B g / I I, M / u I, P s t$, SmaI, Stul and Hind III. The digested samples were electrophoresed through a $1^{\circ}$ gel of low melting point agarose (BRL) and then the bands stained with ethidium bromide $\left(0.5 \mu \mathrm{g} \mathrm{ml}{ }^{-1}\right.$ in $\left.\mathrm{H}_{2} \mathrm{O}\right)$ were excised. After melting the gels $\left(65^{\circ} \mathrm{C}, 30 \mathrm{~min}\right)$, a portion $(10 \mu \mathrm{l})$ of the gel containing each fragment was used for transformation.

Preparation of DNA. B. suhtilis chromosomal DNA was purified as described by Saito \& Miura (1963). Phage particles $(\rho 11$ and $\phi 105)$ and their DNA were prepared by methods essentially similar to those described by lijima ' $t$ al. (1980). After phages had been induced with mitomycin C, phage particles were sedimented in the presence of polyethylene glycol (Yamamoto 't $a l ., 1970$ ) anc further purified by centrifugation through discontinuous $\mathrm{CsCl}$ gradients. Viral DNA was prepared trom purified phage particles by phenol treatment. Plasmid pC194 was prepared as described by Gryczan e't al. (1978).

Restriction nuclease reactions and agarose gel electrophoresis. Manufacturer's specifications were used for restriction enzyme digestions of plasmid and phage DNAs. Agarose gel electrophoresis was done with a horizontal submerged gel apparatus in Löening's buffer (Löening, 1968).

\section{RESULTS}

\section{Mapping and characterization of gnt mutations}

Mapping of the gnt-4 mutation by PBS1-mediated transduction has been reported by Fujita $\&$ Fujita (1983). The map order from sacA to pur $A$ is as follows: sac $A$, thiC, hsrE, iol-6, gnt-4, fdp$74, h s r B, t s 199$ and $\operatorname{pur} A$. The $\triangle i g f$ deletion covers loci from iol-6 to $h s r B$. In this study, the map locations of several other gnt mutations were determined. The gnt -9 mutation was also located within the $\Delta i g f$ deletion because DNA from strain $61656(\Delta i g f)$ could not transform strain YF029 (gnt-9) to $\mathrm{Gnt}^{+}$. PBSI transduction crosses revealed a map order of iol-6, gnt -9 and $f d p-$ 74. When strain YF029 (gnt-9 purA 16) was transduced with PBSl propagated in strain YF127 (gnt-4) and then $\mathrm{Pur}^{+}$recombinants were selected, two $\mathrm{Gnt}^{+}$colonies were found among 161 Pur $^{+}$recombinants. These results suggested that $g n t-9$ is very close to $g n t-4$, perhaps located between $g n t-4$ and $f d p-74$. All of the gnt mutations in our collection, including those that had been newly isolated, gnt-10, gnt-23 and $g n t-26$, were mapped by two-factor transformation crosses between $\mathrm{Gnt}^{-}$strains measuring recombination indexes (Fig. 1). The crosses suggested a map order of gnt-10, gnt-4, gnt-26, gnt-23 and gnt-9. 


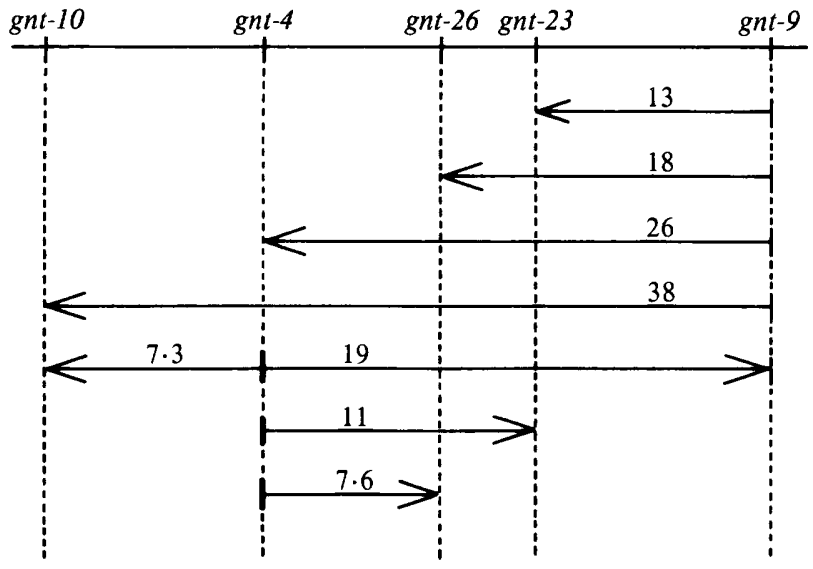

Fig. I. Map of the gnt locus deduced from transformation crosses. In the crosses, YF141 (gnt-4 trpC2 metB5 hisAl) and YF029 (gnt-9 purAl6 leuA8 metB5 hisA3) were used as recipients and strains YF160, YFl61, YFI62, YF127 and YFl64 (gnt-9 purAl6 leuA8 metB5) as donors. Distances are expressed as recombination indexes (Chasin \& Magasanik, 1968). The ratio of gnt $^{+}$to his $^{+}$(YF141 as recipient) or $l e u^{+}$(YF029 as recipient) transformants was a measure of the relative frequency of transformation to gluconate utilization.

\section{Table 1. Induction of gluconate permease and gluconate kinase in gnt mutants}

Gluconate kinase and permease were induced and assayed as described in Methods. Values are means of duplicate assays. Data are from a representative experiment using a complete set of the gnt mutants. Similar independent experiments were repeated at least twice.

\begin{tabular}{|c|c|c|c|c|}
\hline \multirow[b]{2}{*}{ Strain } & \multicolumn{2}{|c|}{ Gluconate permease* } & \multicolumn{2}{|c|}{ Gluconate kinase $\dagger$} \\
\hline & Not induced & Induced & Not induced & Induced \\
\hline $60015\left(g^{+} t^{+}\right)$ & $1 \cdot 14$ & $12 \cdot 39$ & 0.4 & $25 \cdot 4$ \\
\hline $61656(\Lambda i g f)$ & $0 \cdot 15$ & $0 \cdot 15$ & $<0 \cdot 1$ & $<0 \cdot 1$ \\
\hline YF029 $(g n t-9)$ & 0.09 & $0 \cdot 15$ & $<0 \cdot 1$ & $3 \cdot 3$ \\
\hline YF127 (gnt-4) & $34 \cdot 45$ & $26 \cdot 14$ & $<0 \cdot 1$ & $<0 \cdot 1$ \\
\hline YF160 (gnt-10) & $2 \cdot 56$ & $12 \cdot 82$ & $<0 \cdot 1$ & $3 \cdot 9$ \\
\hline YFl61 (gnt-23) & 0.06 & 0.48 & $0 \cdot 1$ & 19.0 \\
\hline YF162 (gnt-26) & $0 \cdot 37$ & $5 \cdot 25$ & $0 \cdot 1$ & $35 \cdot 1$ \\
\hline
\end{tabular}

Since the enzymes involved in gluconate metabolism are supposed to be gluconate kinase and permease, the inducibility of these two enzymes in the $\mathrm{Gnt}^{-}$mutants was investigated (Table 1). As expected, strain 61656 ( $\Lambda$ igf) could induce neither the kinase nor the permease; the $\Delta i g f$ mutation is a large deletion covering the gnt locus. Strain YF029 (gnt-9) could not induce the two enzymes as normal. Since the gnt -9 mutation was considered to be a point mutation, this strain seemed to be impaired in a regulatory function required for the induction of both enzymes. Strain YF160 (gnt-10) was impaired only in the induction of the kinase, whereas strains YF161 (gnt-23) and YF162 (gnt-26) were impaired only in the induction of the permease. The former mutation seemed to be located within the structural gene of the kinase and the latter mutations were likely to be within that of the permease. Strain YF127 (gnt-4) could not induce the kinase at all, but unexpectedly this strain synthesized the permease constitutively.

\section{Cloning of the $\mathrm{gnt}^{+}$fragment in the temperate phage $\phi 105$}

An EcoRI $g n t^{+}$fragment from B. subtilis Marburg 168 (trpC2) DNA containing the genes for gluconate utilization has been cloned in a temperate phage, $\rho 11$, by prophage transformation 
Table 2. Enzyme induction and repression by glucose in the $\Delta$ igf strain lysogenic for $\phi 105 \mathrm{gnt}^{+}$

\begin{tabular}{|c|c|c|c|c|c|c|}
\hline \multirow[b]{2}{*}{ Strain } & \multicolumn{3}{|c|}{ Gluconate permease* } & \multicolumn{3}{|c|}{ Gluconate kinase $\dagger$} \\
\hline & $\begin{array}{c}\text { Not } \\
\text { induced }\end{array}$ & Induced & $\begin{array}{c}\text { Induced } \\
(+ \text { glucose }) \ddagger\end{array}$ & $\begin{array}{c}\text { Not } \\
\text { induced }\end{array}$ & Induced & $\begin{array}{c}\text { Induced } \\
(+ \text { glucose })_{+}^{+}\end{array}$ \\
\hline $60015\left(g n t^{+}\right)$ & 0.71 & $10 \cdot 00$ & 0.63 & $0 \cdot 1$ & $22 \cdot 8$ & $0 \cdot 6$ \\
\hline $61656(\Lambda i f g)\left(\phi 105 g n t^{+}\right)$ & 0.61 & $8 \cdot 66$ & 0.56 & $0 \cdot 9$ & $28 \cdot 5$ & $0 \cdot 1$ \\
\hline
\end{tabular}

using strain 61656 as recipient (Fujita et al., 1983). Moreover, Fujita et al. (1983) tentatively suggested that the $g n t^{+}$fragment contains the structural gene of the gluconate kinase and its regulatory region. However, it was very difficult to isolate the $g n t^{+}$fragment of the recombinant phage by agarose gel electrophoresis because EcoRI digestion of $\rho 11$ DNA produces more than 25 fragments (Mizukami et al., 1980). To isolate and analyse the $g n t^{+}$ fragment, it was recloned in another temperate phage, $\phi 105$, that is relatively small, and convenient for isolation of this fragment (Iijima et al., 1980). DNA $(5 \mu \mathrm{g})$ of phage $\rho 11$ his $A^{+} g n t^{+} \mathrm{E}$ (a recombinant $\rho 11$ possessing the $g n t^{+}$fragment) and DNA (10 $\left.\mu \mathrm{g}\right)$ of phage $\phi 105$ were each completely digested with $E c o$ RI. The digestion products were mixed and ligated using T4 DNA ligase and then used to transform strain 61656 ( $\Delta$ igf), lysogenic for $\phi 105$, to $\mathrm{Gnt}^{+}$. All of the $250 \mathrm{Gnt}^{+}$transformants obiained were considered to result from the integration of the $g_{n t^{+}}$fragment at the site of the $\phi 105$ prophage genome, because of the absence of homology between this fragment and the chromosome of the $\Delta i g f$ strain. Five transformants were treated with mitomycin $C$ and at the same time infected with wild-type $\phi 105$. All the lysates obtained exhibited the ability to transduce strain 61656 to $\mathrm{Gnt}^{+}$. One of the $\mathrm{Gnt}^{+}$ transductants was used for further experiments after single colony isolation. This transductant produced, upon induction, a $g n t^{+}$specialized transducing phage $\left(\phi 105 g n t^{+}\right)$in the absence of helper phage $\phi 105$, but the resulting phage required helper for transduction of a $\mathrm{Gnt}^{-}$recipient to $\mathrm{Gnt}^{+} . \phi 105 g n t^{+}$could transduce not only the $\Delta i g f$ mutant but also strains carrying all the $g n t$ mutations (gnt-4, gnt-9, gnt-10, gnt-23 and gnt-26) to $\mathrm{Gnt}^{+}$.

The inducibility of the gluconate kinase and permease in a $\phi 105 g n t^{+}$lysogen of strain 61656 ( $\Delta i g f)$ was compared with that in our standard strain 60015 (Table 2). Strain $61656\left(\phi 105 g n t^{+}\right)$ induced the two enzymes at normal levels upon addition of gluconate to medium, and induction was repressed by the addition of glucose. The results clearly indicated that the structural genes of the gluconate kinase and permease and regulatory regions for their expression had been cloned in $\phi 105$.

DNA from $\phi 105$ and $\phi 105 g n t^{+}$was digested with $E c o$ RI and analysed by agarose gel electrophoresis (Fig. $2 a$ ). $\phi 105$ DNA produced nine fragments (from A to I) whereas $\phi 105 g n t^{+}$ DNA produced a new fragment of $4.5 \mathrm{MDal}$ (the $g n t^{+}$fragment) and three of the EcoRI fragments of $\phi 105$ DNA (E, G and I) were missing. [The EcoRI cleavage map of $\phi 105 g n t^{+}$DNA is shown with that of $\phi 105$ in Fig. 2(b).] It was ascertained that the $g n t^{+}$fragment was sited between fragments B and D as follows. $\phi 105$ DNA does not contain any $B g / \mathrm{II}$ cleavage sites whereas $\phi 105 g n t^{+}$DNA had one $B g l \mathrm{II}$ cleavage site in the $g n t^{+}$fragment. After digestion of $\phi 105 g n t^{+}$DNA with $B g / I I$, the smaller fragment was isolated by agarose gel electrophoresis. $E c o$ R I digestion of this fragment produced the EcoRI-D fragment, and the $B g / \mathrm{II}-\mathrm{B}$ fragment indicated in Fig. 3(a).

\section{Construction of the restriction enzyme map of the gnt ${ }^{+}$fragment and physical localization of the gnt mutations}

The restriction enzyme map of the $g n t^{+}$fragment was constructed by digestion with $B g l \mathrm{II}$, HindIII, MluI, PstI, PvuII, SmaI and StuI (Fig. 3a). Since the $g n t^{+}$fragment had the ability to 


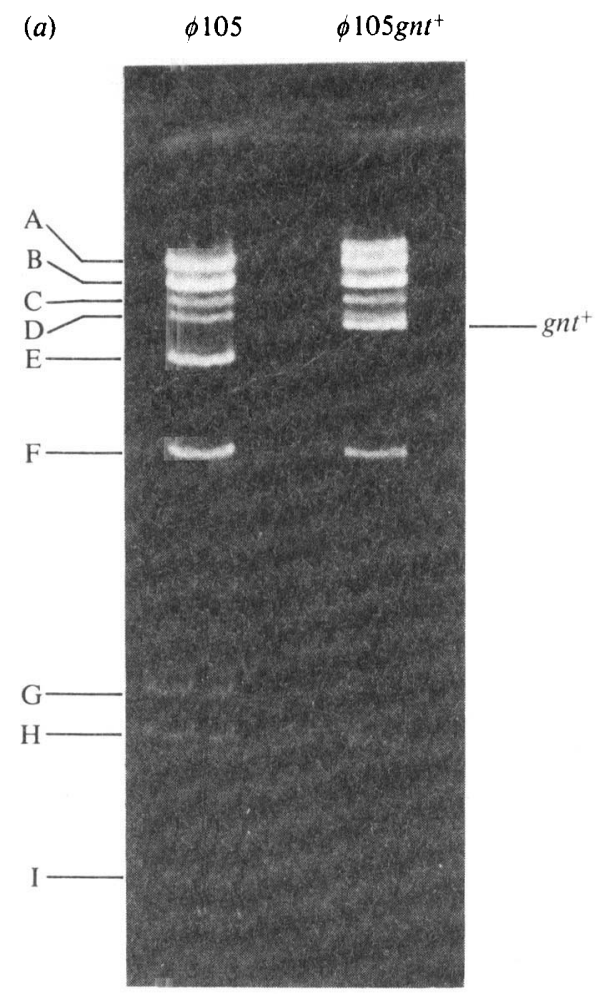

(b)

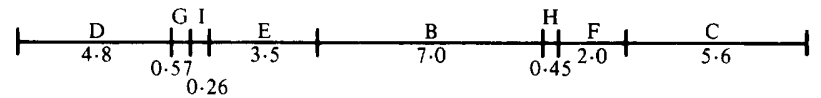

$\phi 105 g n t^{+}$

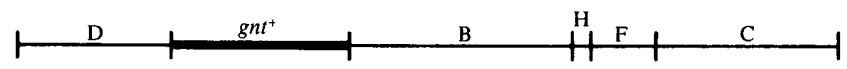

Fig. 2. (a) Agarose gel electrophoresis of EcoRI-digested samples of $\phi 105$ and $\phi 105 g n t^{+}$DNA. The DNA $(2 \mu \mathrm{g})$ was digested with EcoRI and electrophoresed in a $0.8 \%$ agarose gel. (b) Eco RI cleavage maps of $\phi 105$ and $\phi 105 g n t^{+}$DNA, with sizes of fragments expressed as MDal. The map of $\phi 105$ DNA has recently been corrected (Anaguchi et al., 1984; Lampel et al., 1984; Bugaichuk et al., 1984). The cloned $g n t^{+}$fragment (4.5 MDal) is indicated as a bold line.

transform all the $\mathrm{Gnt}^{-}$mutants except the $\Delta i g f$ deletion mutant to $\mathrm{Gnt}^{+}$, we attempted to localize physically each gnt mutation on a particular restriction enzyme fragment by assaying fragments for their ability to transform the respective gnt mutant to $\mathrm{Gnt}^{+}$(Table 3). The BglII-A, MluI-A, PstI-A, SmaI-A, StuI-A and HindIII-A fragments transformed the gnt-4 mutant to the wildtype, while the $B g l \mathrm{II}-\mathrm{A}, M l u \mathrm{I}-\mathrm{A}, P_{s t} \mathrm{I}-\mathrm{A}, S m a \mathrm{I}-\mathrm{B}, S t u \mathrm{I}-\mathrm{B}$ and $H i n d \mathrm{III}-\mathrm{A}$ fragments transformed the gnt-9 mutant to $\mathrm{Gnt}^{+}$. The gnt-10 mutant was transformed with the $B g l \mathrm{II}-\mathrm{B}, M l u \mathrm{I}-\mathrm{B}, P s t \mathrm{I}-\mathrm{B}$, SmaI-A, StuI-A and HindIII-A fragments, whereas the gnt-26 mutant was transformed with the BglII-A, MluI-A, PstI-A, SmaI-A, StuI-B and HindIII-A fragments. The gnt-23 mutant was transformed with $B g / \mathrm{II}-\mathrm{A}, M l u \mathrm{I}-\mathrm{A}, P s t \mathrm{I}-\mathrm{A}$ and $H i n d I I I-A$ fragments. The reversion frequency of the gnt-23 mutation was extraordinarily high so that we could not conclude with confidence which of the $S t u I$ and $S m a I$ fragments exhibited the transforming activity. From these results, each gnt mutation was localized on the respective enzyme fragment (Fig. 3b). (The gnt-23 mutation could be localized approximately between the MluI site and the right-hand HindIII site.) 
(a)

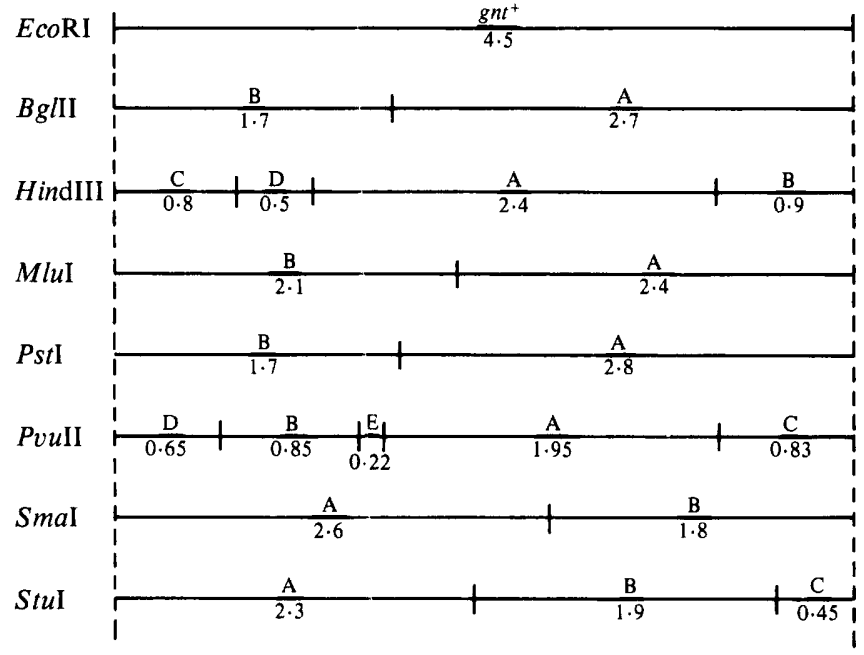

(b)

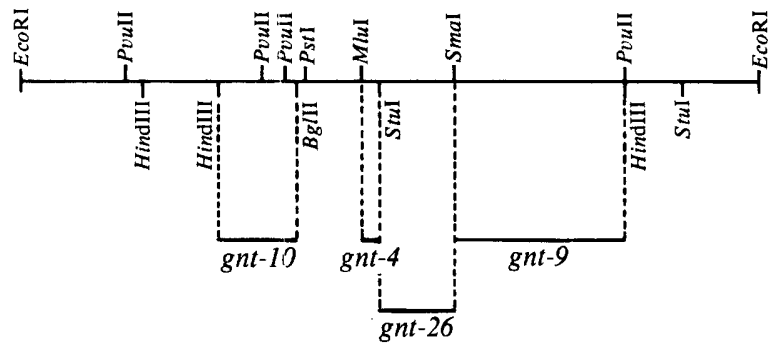

Fig. 3. (a) Restriction enzyme map of the $g n t^{+}$iragment. Fragments generated by BglII, HindIII, MluI, PstI, PrulI, Smal and Stul digestion were alphabetically named; their sizes are expressed as MDal. (b) Localization of $g n t$ mutations. This was deduced from the results of transformation experiments using fragments shown in (a) (Table 3 ). Transformation experiments were independently repeated at least twice using each recipient and various sets of restriction enzyme fragments; all the results obtained supported the locations shown.

\section{Table 3. Gnt ${ }^{+}$transforming activities of restriction enzyme fragments of the gnt $^{+}$fragment}

The transformation was done as described in Methods. Independent transformation experiments were done for each recipient. Values are means of duplicate assays.

\begin{tabular}{|c|c|c|c|c|c|}
\hline \multirow[b]{2}{*}{ Donor fragment } & \multicolumn{5}{|c|}{$\begin{array}{c}\text { No. of } \mathrm{Gnt}^{+} \text {colonies per } 0.1 \mathrm{ml} \text { competent } \\
\text { culture }\end{array}$} \\
\hline & $\begin{array}{l}\text { YF127 } \\
g n t-4\end{array}$ & $\begin{array}{c}\text { YF029 } \\
\text { gnt-9 }\end{array}$ & $\begin{array}{l}\text { Recipient: } \\
\text { YF160 } \\
\text { gnt-10 }\end{array}$ & $\begin{array}{l}\text { YF161 } \\
\text { gnt-23 }\end{array}$ & $\begin{array}{l}\text { YF162 } \\
\text { gnt-26 }\end{array}$ \\
\hline$B g / \mathrm{II}-\mathrm{A}$ & 600 & 1300 & 25 & 810 & 1100 \\
\hline$B g / I l-B$ & 1 & 95 & 380 & 186 & 76 \\
\hline MluI-A & 65 & 550 & 37 & 450 & 660 \\
\hline MluI-B & 8 & 128 & 900 & 210 & 110 \\
\hline Pst $\mathrm{I}-\mathrm{A}$ & 442 & 1170 & 44 & 280 & 300 \\
\hline Pstl-B & 2 & 83 & 440 & 175 & 57 \\
\hline SmaI-A & 1000 & 83 & 4000 & 230 & 180 \\
\hline SmaI-B & 7 & 216 & 18 & 190 & 91 \\
\hline StuI-A & 192 & 95 & 2800 & 220 & 56 \\
\hline StuI-B & 1 & 212 & 38 & 250 & 174 \\
\hline HindIII-A & 630 & 340 & 1500 & 770 & 910 \\
\hline No addition & 0 & 80 & 8 & 193 & 95 \\
\hline
\end{tabular}


Table 4. Induction of gluconate permease and gluconate kinase in $\Delta i g f$ strains bearing plasmids or $\phi 105$ derivatives containing the HindIII-A fragment

\begin{tabular}{|c|c|c|c|c|}
\hline \multirow{2}{*}{$\begin{array}{l}\text { Plasmid } \\
\text { or phage }\end{array}$} & \multicolumn{2}{|c|}{ Gluconate permease* } & \multicolumn{2}{|c|}{ Gluconate kinase $\dagger$} \\
\hline & Not induced & Induced & Not induced & Induced \\
\hline pCG 1 & $5 \cdot 36$ & $4 \cdot 02$ & $28 \cdot 6$ & $15 \cdot 9$ \\
\hline pCG8 & $16 \cdot 08$ & $9 \cdot 15$ & $73 \cdot 6$ & $49 \cdot 5$ \\
\hline$\phi 105 g n t^{+} \mathrm{H} 2$ & $2 \cdot 76$ & $2 \cdot 85$ & $16 \cdot 2$ & $11 \cdot 0$ \\
\hline \multirow[t]{2}{*}{$\phi 105 g n t^{+} \mathrm{H} 4$} & $3 \cdot 71$ & $3 \cdot 05$ & $25 \cdot 0$ & $20 \cdot 2$ \\
\hline & $\begin{array}{l}{ }^{*} \mathrm{nmol} \\
\dagger \mathrm{nmol}\end{array}$ & $\begin{array}{l}\text { per } \mathrm{u} \\
\mathrm{mg}^{-1}\end{array}$ & & \\
\hline
\end{tabular}

\section{Cloning of the HindIII-A fragment with $p C 194$ and $\phi 105$ and its expression}

To investigate the effect of high copy number on the regulation of the expression of the cloned genes, we attempted to clone the $g n t^{+}$fragment in plasmid pUB110; these experiments failed, perhaps because the fragment was too large to be cloned in this plasmid. As an alternative approach we decided to clone the HindIII-A fragment $(2.4 \mathrm{MDal})$ in another plasmid, pC194, because this fragment was smaller, but nevertheless was able to correct all the gnt mutations in transformation experiments. The HindIII-A fragment $(2 \mu \mathrm{g})$ was isolated electrophoretically from a HindIII-digested sample of the $\mathrm{gnt}^{+}$fragment, and was ligated with pC194 $(2 \mu \mathrm{g})$ that had been digested with HindIII. The ligated DNA was used to obtain $\mathrm{Gnt}^{+}$transformants of strain YF158 (gnt-4 recE4 trpC2). Out of $187 \mathrm{Gnt}^{+}$colonies obtained, ten colonies were used for plasmid extraction and analysis. Two kinds of plasmid (represented by pCG1 and pCG8) were found in which the HindIII-A fragment was cloned in opposite orientations. Strain $61656(\Delta i g f)$ transformed with each plasmid was used for further experiments. The inducibility of the gluconate permease and kinase in strain $61656(\Delta i g f)$ harbouring pCG1 or pCG8 [61656(pCG1 or pCG8)] was investigated. The two enzymes were synthesized constitutively in both 61656(pCG1) and 61656(pCG8) (Table 4). Specific activities of the enzymes synthesized in 61656(pCG8) were $2-3$ times higher than those in 61656(pCG1).

The constitutive synthesis of the gluconate permease and kinase might possibly be attributed to the presence of multiple copies of the HindIII-A fragment containing pCG1 or pCG8. To test this possibility, the HindIII-A fragment was cloned in the genome of $\phi 105$, which can be integrated as only one copy in the host chromosome, and the expression of the genes in this fragment was investigated. The HindIII-A fragment was cloned by prophage transformation using $61656(\Delta i g f)$ as recipient and using similar procedures to those described above. From two $\mathrm{Gnt}^{+}$transducing phages obtained $\left(\phi 105 g n t^{+} \mathrm{H} 2\right.$ and $\left.\phi 105 g n t^{+} \mathrm{H} 4\right)$, DNA was prepared, digested with restriction enzymes and analysed by agarose gel electrophoresis. The electrophoretic patterns of the EcoRI- and the EcoRI + HindIII-digested samples of $\phi 105 g n t^{+} \mathrm{H} 2$ were different from those of $\phi 105 g n t^{+} \mathrm{H} 4$, but the doubly digested DNA samples gave a band of $2.4 \mathrm{MDal}$ that corresponded to the HindIIII-A fragment (data not shown). The results indicated that $\phi 105 g n t^{+} \mathrm{H} 2$ and $\mathrm{H} 4$ possess the HindIII-A fragment cloned in different HindIII sites of $\phi 105$. Table 4 shows that strain 61656 lysogenic for either $\phi 105 g n t^{+} \mathrm{H} 2$ or $\mathrm{H} 4$ synthesized the gluconate kinase and permease constitutively. The results imply that the constitutive synthesis of the two enzymes in strains carrying pCG1 or pCG8 was not due to the high copy number of the fragment when cloned in $\mathrm{pC} 194$, but rather that a regulatory function required for the induction of the enzymes was lacking in the fragment.

\section{DISCUSSION}

All of the mutations affecting the gluconate permease and kinase and the regulation of their biosynthesis were found to be clustered. On the basis of two factor crosses between $\mathrm{Gnt}^{-}$ mutants (Fig. 1), we distinguished on the map the gnt-10 mutation and the gnt-23 and gnt-26 mutations in the structural genes of the kinase and the permease, respectively. The existence of 
the gnt -9 mutation affecting both the permease and the kinase, and the fact that the $\Lambda$ igf strain lysogenic for $\phi 105 g n t^{+} \mathrm{H} 2$ or $\mathrm{H} 4$ constitutively synthesized the two enzymes, suggested that the two structural genes belong to a single transcription unit, a gluconate $(g n t)$ operon. However, we have not excluded the possibility that there are two separate transcription units controlled by the same regulators. The presence of the gnt-4 mutation affecting the kinase and causing the constitutive synthesis of the permease is not completely understood. However, at present, we prefer one of the possible explanations, i.e. that the gluconate kinase protein itself may be involved in the regulation of the gluconate operon, so that the impaired gluconate kinase produced in the gnt-4 mutant might cause the constitutive synthesis of the permease.

We previously reported the cloning of the structural gene of the gluconate kinase and regulatory regions for its expression in a phage, $\rho 11$ (Fujita et al., 1983). In this investigation, an $E c o \mathrm{RI} g n t^{+}$fragment generated from DNA of the specialized $g n t^{+}$transducing phage $\rho 11$ was recloned in another temperate phage, $\phi 105$. The fact that the induction of the gluconate permease and kinase in the $\Lambda$ igf strain lysogenic for $\phi 105 g n t^{+}$was indistinguishable from that in the wild-type strain (Table 2), and that $\phi 105 g n t^{+}$was able to transduce the $\Delta i g f$ deletion as well as all the gnt mutants to $\mathrm{Gnt}^{+}$, strongly indicated that an intact gluconate operon had been cloned in $\phi 105$. The HindIII-A fragment as well as the $g n t^{+}$fragment (Table 3) was able to transform all the gnt mutants to the wild-type. However, the $\Delta i g f$ strain lysogenic for $\phi 105$ bearing this fragment synthesized the gluconate permease and kinase constitutively. This suggests that the HindIII-A fragment probably contains the structural genes of the two enzymes, but does not contain any of the regulatory region of the gluconate operon.

The map order of $g n t-10$, gnt-4, gnt-26, gnt-23 and gnt-9 (Fig. 1) is considered to be tentative because it is based on data from two-factor crosses. However, it was not possible to carry out three-factor transformation crosses because at present there is no known easily selectable marker that is linked to the gnt mutations. Moreover, these mutations were too close to be ordered by PBS1 transduction crosses. All of the gnt mutations were successfully assigned to restriction enzyme fragments generated from the $g n t^{+}$fragment (Fig. $3 b$ ). Although the map order of the gnt mutations is tentative, it is likely to be reliable because it is reasonably consistent with the physical map. The $g n t^{+}$fragment does not complement the $i o l-6$ and $f d p-74$ mutations (Fujita et al., 1983), but it did complement all the gnt mutations. From these results and those obtained from the genetic crosses, the following order from iol-6 to $f d p-74$ was deduced: iol-6, gnt-10, gnt-4, gnt-26, gnt-23, gnt-9 and fdp-74.

We thank H. Saito and F. Kawamura for valuable suggestions. M. Fujita encouraged us throughout the course of this work.

This work was supported in part by a grant in aid for scientific research from the Ministry of Fducation, Science and Culture of Japan.

\section{REFERENCES}

Anaguchi, H., Fukui, S. \& Kobayashi, Y. (1984). Revised restriction maps of Bacillus subtili:; bacteriophage $\phi 105$ DNA. Journal of Bacteriology 159, 1080 1082.

Bugaichuk, U. D., Deadman, M., Errinciton, J. \& SavVA, D. (1984). Restriction enzyme analysis of Bacillus subtilis bacteriophage $\phi 105$ DNA. Journal of General Microbiolog! 130, 2165 2167.

Chasin, L. A. \& MaGasanik, B. (1968). Induction and repression of the histidine-degrading enzymes of Bacillus subtilis. Journal of Biological Chemistry 243, 5165-5178

Dowds, B., Baxter, L. \& MCKillen, M. (1978). Catabolite repression in Bacillus subtilis. Biochimica et biophysica acta 541, 18-34.

FuJita, Y. \& FREESE, E. (1981). Isolation and properties of a Bacillus subtilis mutant unable to produce fructose-bisphosphatase. Journal of Bacteriology 145, 760 767.

Fujita, Y, \& Fujita, T. (1983). Genetic analysis of a pleiotropic deletion mutation $(\wedge i g f)$ in Bacillus subtilis. Journal of Bacteriolog! 154, 864869.

Fujita, Y, Fujita, T., Kawamura, F. \& Saito, H. (1983). Efficient cloning of genes for utilization of Dgluconate of Bacillus subtilis in phage $\rho$ ll. Agricultural and Biological Chemistry 47, 1679-1682.

Gryczan, T. J., Contente, S. \& Dubnau, D. (1978). Characterization of Staphylococcus aureus plasmids introduced by transformation into Bacillus subtilis. Journal of Bacteriology 134, 318-329.

Iijima, T., Diesterhaft, M. D. \& Freese, E. (1977). Sodium effect of growth on aspartate and genetic 
analysis of a Bacillus subtilis mutant with high aspartase activity. Journal of Bacteriology' 129, 14401447.

Iijima, T., Kawamura, F., Saito, H. \& Ikeda, Y. (1980). A specialized transducing phage constructed from Bacillus subtilis phage $\phi 105$. Gene 9, 115-126.

Lampel, J. S., Ellis, D. M. \& Dean, D. H. (1984). Reorienting and expanding the physical map of temperate Bacillus subtilis bacteriophage $\phi 105$. Journal of Bacteriology 160, 1178-1180.

LÖENING, U. E. (1968). Molecular weights of ribosomal RNA in relation to evolution. Journal of Molecular Biology 38, 355-365.

Mizukami, T., Kawamura, F., Takahashi, H. \& SaITo, H. (1980). A physical map of the genome of the Bacillus subtilis temperate phage $\rho 11$. Gene 11, 157-162.
Nihashi, J. \& Fujita, Y. (1984). Catabolite repression of inositol dehydrogenase and gluconate kinase syntheses in Bacillus subtilis. Biochimica et biophysica acta 798, 88-95.

Saito, H. \& MiUra, K. (1963). Preparation of transforming deoxyribonucleic acid by phenol treatment. Biochimica et biophysica acta 72, 619.

Shibata, T. \& SaIto, H. (1973). Repair of ultravioletinduced DNA damage in the subcellular systems of Bacillus subtilis. Mutation Research 20, 159-173.

Yamamoto, K. R., Alberts, B. M., Benzinger, R., LAWHORne, L. \& Treiber, G. (1970). Rapid bacteriophage sedimentation in the presence of polyethylene glycol and its application to large-scale virus purification. Virology 40, 734-744. 